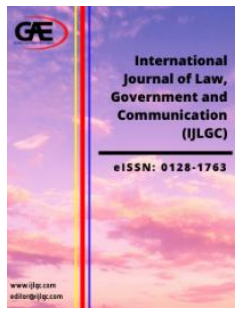

\author{
INTERNATIONAL JOURNAL OF LAW, \\ GOVERNMENT AND COMMUNICATION \\ (IJLGC) \\ www.ijlgc.com
}

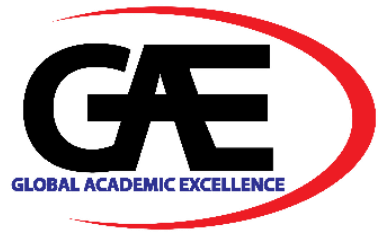

\title{
THE MEDIATING EFFECT OF ATTITUDE ON THE RELATIONSHIPS BETWEEN WHATSAPP USAGE, KNOWLEDGE, AND BEHAVIORAL IMPACT
}

\author{
Md Saydul Haque ${ }^{1 *}$, Saodah Wok $^{2}$ \\ 1 Department of Communication, International Islamic University Malaysia \\ Email: saydulhaque.iium@gmail.com \\ 2 Department of Communication, International Islamic University Malaysia \\ Email: wsaodah@iium.edu.my \\ Corresponding Author
}

\section{Article Info:}

Article history:

Received date: 04.10 .2020

Revised date: 15.10 .2020

Accepted date: 09.12.2020

Published date: 13.12 .2020

\section{To cite this document:}

Haque, M. S., \& Wok, S. (2020). The Mediating Effect of Attitude on The Relationships Between WhatsApp usage, Knowledge, and Behavioral Impact. International Journal of Law, Government and Communication, 5 (21), 160-181.

DOI: $10.35631 /$ IJLGC.5210012.

This work is licensed under CC BY 4.0

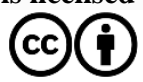

\section{Abstract:}

With millions of users worldwide, WhatsApp has truly become an outstanding and one of the quickest developing information exchange platforms that the modern world has ever seen. The application offers many useful features to people all around the world. More specifically, its use has remarkably changed how lecturers and students communicate and share information. With this in mind, this study attempts to investigate the effect of WhatsApp usage in a tertiary educational institution in Malaysia. The specific objectives of the study are to determine the level of usage, attitude, knowledge, and behavioral impact of WhatsApp communication; to analyze the relationships between behavioral impact, usage, knowledge, and attitude in using WhatsApp communication; and to test the mediating effect of attitude on the relationships between WhatsApp usage, knowledge, and behavioral impact. The underlying theory used in this study is the media richness theory. The study employed the quantitative research design with the survey method and online questionnaire as the research instrument for data collection. A total of 161 respondents from International Islamic University Malaysia (IIUM) participated in the study. The results revealed a high level of WhatsApp usage, a positive attitude, high knowledge, and a positive behavioral impact of WhatsApp communication among IIUM postgraduate students. Attitude partially mediated the relationships of WhatsApp usage and knowledge with behavioral impact.

Keywords:

Behavioral Impact, IIUM, Malaysia, Tertiary Education, WhatsApp Communication 


\section{Introduction}

Given the advent of groundbreaking scientific innovations, technology has made our life easier. Social media is very common and popular among people from all walks of life, be it student, employee, or employer. Social media is becoming predominant because of its ability to address the issue of socializing among people. It plays an important role in socialization, particularly through Facebook and Twitter. Other than social media platforms, some messaging apps also allow people to connect socially. WhatsApp is one such platform that connects people not only through messaging but also through stories, groups, and other activities that are found in the app. Given the effectiveness of WhatsApp messenger as a tool for enabling mobile learning, Fattah (2015) indicated that the learning environment has changed to suit the availability and accessibility of such a platform in modern times.

With the advent of WhatsApp, the spreading of information worldwide has become easier and faster. WhatsApp is popular as an instant messaging app for smartphones, tablets, and computers. Developed in 2009, WhatsApp was introduced by former Yahoo employees Brian Acton and Jan Koum. WhatsApp Messenger works with Internet connectivity, which incurs zero cost to its users. The WhatsApp application is compatible with most iPhones, Android, Blackberry, Windows Smartphones, and Nokia (Patel, 2014).

Nowadays, higher learning institutions worldwide give some importance to using WhatsApp as a study tool. In an institution like International Islamic University Malaysia (IIUM), WhatsApp is commonly used by students and lecturers. In communication between students and lecturers, WhatsApp plays a vital role that cannot be ignored. In the past, sharing information with classmates and lecturers at once was quite challenging and time-consuming since it required e-mailing all recipients by typing all their e-mail addresses. However, with WhatsApp, there is an option to create groups whereby instant messages, images, audio and video files to and from students and instructors can be sent and received. As a teaching tool, WhatsApp is arguably more helpful for teachers since they can upload lecture notes in the WhatsApp group where all students can receive those notes easily. Also, important announcements can be made through WhatsApp to enable students to receive alerts instantly. WhatsApp groups can assume the role of a virtual classroom where students can ask questions to lecturers and likewise, lecturers can answer their questions simultaneously. Features of WhatsApp messenger include videos, text messages, images and voice notes, group chats, unlimited messaging, and cross-platform engagements (Bere, 2013).

WhatsApp is easily accessible to students as all postgraduate students own smartphones or tablets equipped with Internet access. WhatsApp Messenger can provide a useful way for IIUM postgraduate students to stay in touch with their lecturers. Also, WhatsApp messenger can make their academic life easier in terms of obtaining information from their classmates and lecturers. Students can also keep in touch with friends and family members, as well as using it to share ideas, thoughts, and emotions to satisfy their information, entertainment, and learning requirements (Jisha \& Jebakumar, 2014). 


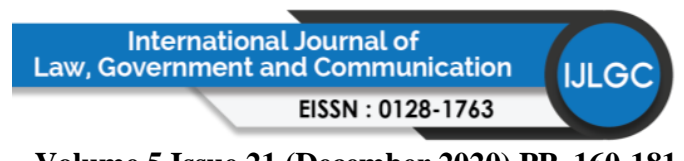

Volume 5 Issue 21 (December 2020) PP. 160-181

DOI 10.35631/IJLGC.5210012

\section{Problem Statement}

While WhatsApp is being used as a learning tool in many higher education institutions, a low level of its usage can cause difficulties in the academic life of IIUM postgraduate students. The learning process can be affected due to the lack of usage of WhatsApp as a communication tool among IIUM postgraduate students. The use of different instant messaging platforms in education is also determined by the instantaneous applications to improve the learning process (Smit, 2012). However, the tendency to use short forms of words in WhatsApp messenger may affect students' grammatical and spelling skills.

The question is, do students know the capability and ability of WhatsApp? Do they like it and use it in communicating with peers and lecturers?

\section{Research Objectives}

The main objective of the study is to assess the mediating effect of attitude on the relationships of usage and knowledge with behavioral impact in using WhatsApp among IIUM postgraduate students. The specific objectives are:

1. To determine the level of usage, attitude, knowledge, and behavioral impact of WhatsApp communication;

2. To analyze the relationships between usage, knowledge, attitude, and behavioral impact in using WhatsApp; and

3. To test the mediating effect of attitude in using WhatsApp communication on the relationships between usage, knowledge, and behavioral impact.

\section{Significance of the Study}

The findings of this study are expected to contribute to the body of knowledge in WhatsApp usage and social networking sites in general through the framework of media richness theory. The theory has been used before in similar studies but not at IIUM, specifically in assessing the mediating effect of attitude on the relationships of usage and knowledge with behavior. Minimal research has been carried out on the effects of social networking sites, specifically WhatsApp usage, on students' behavior particularly in IIUM. Therefore, this paper attempts to fill the gaps in research in this field.

Data from this study are expected to provide useful information to universities on the management of students who constantly use their gadgets during class hours or for study purposes. It will guide them on how to manage students and to find lasting solutions to prevent students from losing their self-esteem resulting from excessive usage of social networking sites.

The findings of the study may help digital marketing specialists by offering valuable insights into the relationship between social networking sites and subsequent user behavior. This is because an increasingly large number of young adults are adopting text-based platforms, for example, WhatsApp for communication rather than the normal text messages and phone calls. Hence, digital marketers can benefit from this study by getting information on who and how to target. This study is also expected to offer insights on how individuals choose what media to engage in (Bryant, Thompson, \& Finklea, 2013; Rubin \& Haridakis, 2008). 


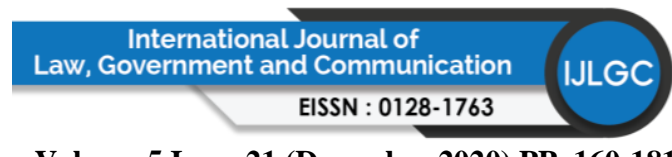

Volume 5 Issue 21 (December 2020) PP. 160-181

DOI 10.35631/IJLGC.5210012

\section{Literature Review}

Social media has become a growing phenomenon worldwide and is being used by the public and academic institutions alike. Any activities where humans share stories and influence others can be considered as social networking (Nicholson, 2011). Social networking is a great platform to discuss mutual topics of interest with others virtually. In educational institutions, a messaging app can be considered as a social networking hub where students and lecturers engage in academic discussions and for other formal communication exchanges.

\section{Social Media}

Social media can be defined as an electronic communication form through which users can interact with others where they can share their thoughts and emotions freely as well as exchange and discuss information and ideas by using a multimedia mix of personal words, pictures, videos and audio, utilizing online platforms while they are connected to the Internet (Cox \& Rethman, 2011). Social media is also identified as a group of Internet-based applications that build on the ideological and technological foundations of the Web and that allow the creation and exchange of user-generated content.

\section{WhatsApp}

WhatsApp is a social network and an American proprietary cross-platform instant messaging client for smartphones (Boyinbode, Agbonifo, \& Ogundare cited in Plana et al., 2013). WhatsApp was founded in 2009 by Jan Koum and Brian Acton. WhatsApp Incorporation is based in Mountain View, California, United States, and it was acquired by Facebook Inc. on February 19, 2014, for approximately USD19.3 billion. The most popular application among smartphone users is WhatsApp messenger. The Digital News Report found that Malaysians are the world's largest users of WhatsApp, having 51 percent users (Bernama, 2017).

\section{WhatsApp in Education}

The world is relentlessly changing due to the rise of new technology and science. Currently, getting away from technology seems unimaginable. Many people opt for numerous technological inventions that are used regularly in their daily activities. A great number of people depend on WhatsApp to be more productive and to learn certain things. Similarly, in the education sector, especially in higher learning institutions, the usage of WhatsApp has increased exponentially with a substantial impact on students and lecturers alike (Yeboah \& Ewur, 2014).

Motiwalla (2007) identified the importance and support of smartphones among students. He opines that many university students achieved their academic goals with the help of text messages using smartphone learning. Similarly, IIUM postgraduate students seem to depend on text-messaging platforms such as WhatsApp for their educational purposes. Indeed, WhatsApp has an important role to play in the field of education. Group studies can be done through WhatsApp groups, where students do not need to be physically present as they can communicate with each other virtually. They can share their thoughts, ideas, and opinions with others in WhatsApp groups, making their educational life easier and more convenient. Besides, Litchfield et al. (2007) revealed that the increasing use of smartphones in educational institutions positively impacted student performance. 


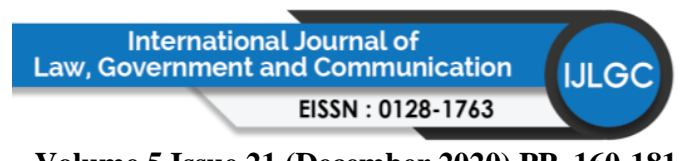

Volume 5 Issue 21 (December 2020) PP. 160-181

DOI 10.35631/IJLGC.5210012

WhatsApp is one of the social media platforms that may benefit students. WhatsApp serves as a texting cross-platform smartphone application that utilizes users' current Internet data and enables them to communicate socially (WhatsApp, 2018). The important reason behind the creation of this application is to substitute the short message service (SMS) system, and it is available for free and merely requires an Internet connection to use. It gives users the ability to send endless texts, providing them with an advantage by bypassing international fees (Yeboah \& Ewur, 2014).

\section{WhatsApp Usage}

WhatsApp plays an important role in the lives of IIUM postgraduate students. Some students find it difficult to ask questions in the classroom in the presence of many people, or some of them are shy to question lecturers through face-to-face communication. Past studies explained that at least $80 \%$ of students in higher education institutions were active in social media (Schultz, 2011). Messaging platforms like WhatsApp allow students to ask questions to their educators virtually. Students seem to be more confident and comfortable clarifying their doubts in lectures through WhatsApp group conversations.

Since WhatsApp allows many people to contribute to a topic simultaneously, its use in education appears beneficial. The environment and the personal characteristics of learners play a crucial role in their academic life. The utilization of WhatsApp in educational institutions can help students to achieve good performance. According to Doering, Lewis, Veletsianos, and Besel (2008), if learning is a social activity that involves constructing identities in practice, then instant messaging with its social and identity-performing affordances is a logical medium to include in the teaching and learning process.

The formation of a good relationship between the teacher and the student is the spirit of education (MacGrath, 2005). Thus, WhatsApp helps in building a positive relationship between students and teachers through virtual communication since they can communicate with each other virtually and they can exchange their emotions using emoticons in WhatsApp. Hence, it is not surprising that WhatsApp has made IIUM postgraduate students' academic life easier and has helped them in achieving their academic goals.

\section{Knowledge of WhatsApp}

Social media platforms allow users to exercise their communication strategies for knowledge creation for sharing and disseminating purposes. The use of social media platforms like WhatsApp enhances business capabilities and performance (Smits \& Mogos, 2013), and organizations can utilize available social media technologies to communicate with the public and to potentially collect valuable information using the public as sources of information on the ground level (Latonero \& Shklovski, 2011).

According to Bers (2010), modern-day learning does not end in the classroom like it was in the past. All students now own Internet-enabled phones. With tools like WhatsApp, students can create knowledge from wherever they are. The feature of WhatsApp, which gives it the ability to connect people at different places, has succeeded in fostering long-distance learning and discussion (Alghamdi, Rajab, \& Rashid, (2016). 
Nchindo Richardson Mbukusa (2018), in the article, "Perceptions of students' on the Use of WhatsApp in Teaching Methods of English as Second Language at the University of Namibia", has reiterated the role of mobile phone devices in gathering and distributing knowledge. Mbukusa has given especial emphasis on WhatsApp and through his study, it is opined that, WhatsApp has a positive correlation with earning knowledge. Mbukusa asserts, "Recently, electronic mobile devices have been widely used for attaining knowledge, asking questions and retrieving information" (Mbukusa, 2008). His primary focus has been on language learning, where Mbukusa claims that WhatsApp "presents itself as one of the inventive teaching methods" that can attract students more efficiently and "provide them with opportunities for further learning" (Mbukusa, 2008). From this study, we can confidently claim that the role of WhatsApp is no longer limited to informal exchange of information, rather it has become a powerful and effective tool for gathering and distributing knowledge including in the tertiary educational institutions.

In their article, Izyani binti Mistar and Mohamed Amin Embi (2016) have presented the effectiveness and impact of WhatsApp in the lives of students in the context of learning in a classroom setting. They opine that, the usage of WhatsApp messaginf app can be one of the "inventive teaching techniques" to grab the attention of the young students of modern generation, who use smartphones extensively (Mistar \& Embi, 2016). They also added the entertainment part of it, the tool provides "fun-based-learning" and thus learning becomes easier to practise. They have also acknowledged that the utilization of the WhatsApp app can positively "increases idea contribution" among the students and gives them a faster and easier communication tool.

Ansiem George, S. Preetha and Pramod S. K (2018) have dealt with an important aspect of using WhatsApp by the students: Social Interaction Anxiety and Personality among Students. Besides discussing the impact of WhatsApp in the study life, they have explored the area of some kind addiction to the app and it is sometimes used from negative light in the context of overuse. Thus, some students end up missing real time communication with people and the app "tempts students to use it more than what is expected" (George, Preetha \& S. K. 2018). In such context, WhatsApp may hinder earning knowledge effectively since it is affecting the lives and behaviors of the students damagingly and undesirably.

\section{Attitude Towards WhatsApp}

Terzi et al. (2019) highlighted that midwifery and nursing students had a positive attitude towards the use of WhatsApp communication for educational purposes. In Australia, Connolly et al. (2019) indicated that students had a more positive attitude in comparison to instructors regarding using WhatsApp for educational purposes. Besides, Khan et al. (2016) showed that accounting students had a positive attitude towards the use of social media in several academicrelated issues. In Greece, Kitsantas et al. (2015) found that female students had a more positive attitude in comparison to male students with regard to professional skills, information, and academic skills.

WhatsApp has been used to enhance learning in expounding research activities. Nassar (2016) found a positive reflection on students' attitudes towards learning where they were also motivated to share information and collaborate with each other and with the instructor. Bere Copyright $\odot$ GLOBAL ACADEMIC EXCELLENCE (M) SDN BHD - All rights reserved 


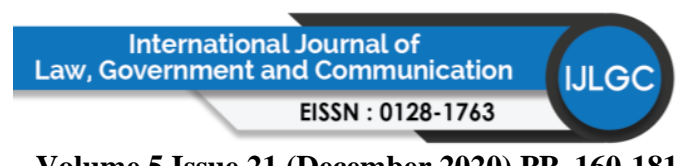

Volume 5 Issue 21 (December 2020) PP. 160-181

DOI 10.35631/IJLGC.5210012

(2013) indicated that students gave positive feedback and claimed that WhatsApp provided an easier way to communicate with their teachers and the rest of the class and that it was also fun. Many students favored using WhatsApp as a tool to support the learning process (Abaido \& El-Messiry, 2016). However, WhatsApp has some negative effects on attitudes such as negative feelings, reduced cognitive development, social isolation.

\section{Behavioral Impact of WhatsApp}

Mehmood and Taswir (2013) examined the influence of social media on undergraduate students' academic performance and social behavior. Social media applications constitute an integral part of students, keeping them connected with their peers and instructors (Abdelraheem \& Al-Rabane, 2005).

WhatsApp unlocks new opportunities for intimate communication to enable the creation of micro-communities and to richly support social practices such as collective lifelogging and reminiscing, to contrast the popular view of WhatsApp as a mere instant messaging tool (Karapanos, Gouveia, \& Teixeira, 2016). At the same time, WhatsApp usage might have an addictive character. Overuse and inappropriate use of WhatsApp are more prominent among students. Knowingly or unknowingly, they become addicted to WhatsApp. They feel a need for a markedly increased amount of time to use this application, avoid taking responsibilities for time, and have difficulty with social and occupational activities. They tend to face physical, psychological, and social problems. Many of them use this application to overcome feelings of depression arising out of stress (Pramod, 2016).

WhatsApp messenger has a drastic impact on the academic performance of students in learning institutions. Despite enabling fast communication and enhancing the effective flow of information and idea-sharing among students, WhatsApp has led to poor performance among students. It is very difficult for young people who are already using smartphones to stop using an app that allows them to communicate in such a simple, immediate, and almost free manner. Hence, it is important to explain the drawbacks of WhatsApp to them and to warn them about the privacy status of their conversations and of the images they send using WhatsApp (Singh $\&$ Franklin, 2015). Also, the authors found a strong association between WhatsApp addiction tendencies and psychological behavioral factors measured by shyness, moody behavior, loneliness, and the feeling of stress among youths in the region of Punjab in India.

Bouhnik and Deshen (2014) noted that there are challenges and problems related to WhatsApp usage. First, not all high school students possess a smartphone. Second, teachers tend to be annoyed by the flood of irrelevant and nonsensical messages, and finally, educational difficulties may arise, such as language incompatibility among students and students' assumption that their teachers should be available on a $24 / 7$ basis.

Chris (2015) stated that social media applications like WhatsApp could negatively impact students' study behavior and academic progress and that timed-off software should be installed to control its use among students. WhatsApp supports students' study habits, particularly during the day but they become addicted to it at night hours, resulting in a negative effect on their examination revision time. 


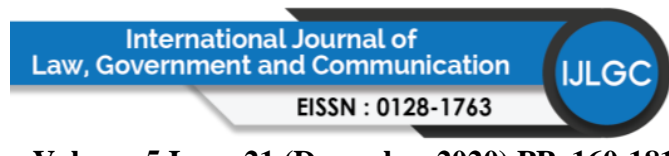

Volume 5 Issue 21 (December 2020) PP. 160-181

DOI 10.35631/IJLGC.5210012

\section{Theory of Media Richness}

In 1986, Richard L. Daft and Robert H. Lengel formulated the theory of media richness (MRT), also known as information richness theory. It is mainly used to describe and evaluate communication media within organizations in terms of their effectiveness. Lan and Sie (2010) defined media richness in terms of content timeliness, content richness, content accuracy, and content adaptability. In this context, WhatsApp groups used for classes are specifically tailored to achieve specific purposes, namely, communicating with students, enhancing social atmosphere, initiating dialogues, and promoting the values of sharing among students as well as for a learning platform.

According to Anandarajan (2010), media richness is more convenient in an Internet-based communication system on a social platform via messaging applications such as WhatsApp. This instant messaging platform has changed customer experience and made text communication more convenient for both senders and receivers. The four dimensions used in this study are immediate feedback, multiplicity of information cues, language variety, and personal focus (Yue, 2014).

First, immediate feedback in communication as the first dimension of media richness theory can be identified as the degree to which receivers of messages give feedback on the messages sent to them (Daft \& Lengel, 1986). Due to the invention and spread of the Internet and technology, Mobile Instant Messages (MIM) has become immensely popular and is being used worldwide on social networking platforms such as Facebook Messenger, Telegram, WhatsApp, and WeChat. Mobile devices have given a quick start to increased communication and connectivity. According to Chaffey (2016), over 90\% of smartphone users' time is spent on apps.

Second, the multiplicity of information cues is defined as the signals of information sent and received. These can exist in the form of verbal cues such as the tone of voice or as non-verbal cues such as gestures or text (written/ spoken words).

Third, media richness theory denotes language variety where numbers or symbols can be used as a rich media. These numbers or symbols of natural language carry numerous ideas, thoughts, and feelings. Riyanto (2013) indicated that WhatsApp can be used to learn new languages. He found positive effects in using WhatsApp to develop writing skills; thus, communication can be improved among students, allowing them to know each other better and leading them towards forming good friendships and good support in their study. Also, Plana (2013) mentioned that the use of WhatsApp increases the willingness to read in a foreign language.

Lastly, when the media concentrates more on personal focus, it can convey the message better. For instance, face-to-face communication can be compared with text messages on WhatsApp. The messaging tool could be useful in creating alternative space for exchanging dialogues among students and lecturers. Through WhatsApp groups, collaborative engagements in informal contexts are possible and the existing teaching and learning will be more engaging and vibrant. 


\section{Conceptual Framework}

Based on the literature review and supported by the media richness theory, the conceptual framework is visualized (Figure 1).

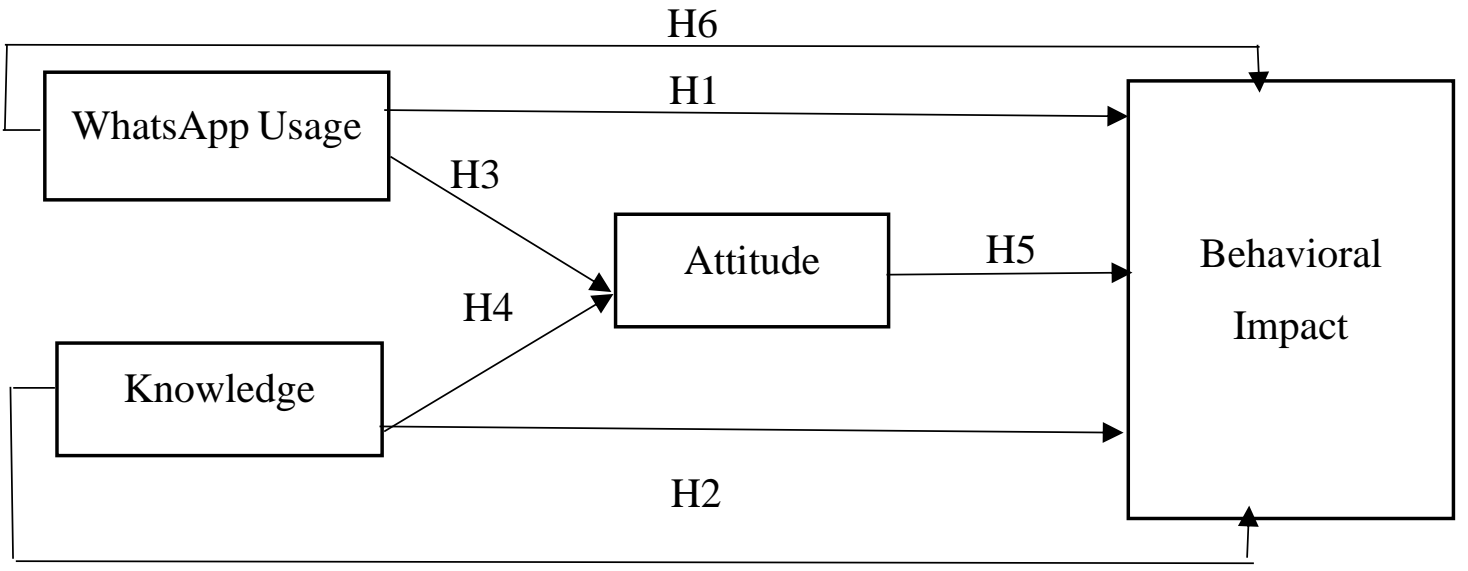

$\mathrm{H} 7$

Figure 1: Conceptual Framework for the Mediating Effect of Attitude on the Relationships Between Behavioral Impact and WhatsApp Usage, and Behavioral Impact and Knowledge Among IIUM Postgraduate Students

\section{Summary of Hypotheses of the Study}

Based on the conceptual framework, the following hypotheses are developed:

H1: There is a positive relationship between WhatsApp usage and behavioral impact.

H2: There is a positive relationship between knowledge and behavioral impact.

H3: There is a positive relationship between WhatsApp usage and attitude.

H4: There is a positive relationship between knowledge and attitude.

H5: There is a positive relationship between attitude and behavioral impact.

H6: Attitude mediates the relationship between WhatsApp usage and the behavioral impact of using WhatsApp.

H7: Attitude mediates the relationship between knowledge and the behavioral impact of using WhatsApp.

\section{Methodology}

\section{Research Design}

This study employed the quantitative research design, using the survey method with an online questionnaire in Google Form as the research instrument for data collection. This was done to facilitate the data collection process in acquiring a huge volume of data within a short timeframe. The online survey questionnaire was distributed to postgraduate students of International Islamic University Malaysia (IIUM). 


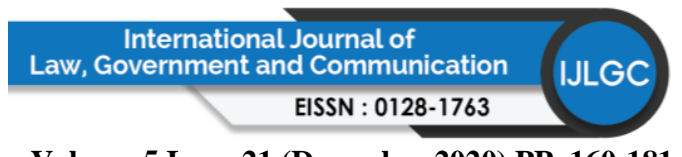

Volume 5 Issue 21 (December 2020) PP. 160-181

DOI 10.35631/IJLGC.5210012

\section{Population and Sampling Procedure}

The postgraduate students of IIUM, a leading public university in Malaysia, were selected as the population of this study. From 18,825 students, 15,625 were undergraduates while the remaining 3,200 were postgraduates (IIUM, 2018).

A target population refers to a specific group of participants who share similar characteristics or have a similar experience. Therefore, the target population of this study consisted of local and international postgraduate students of IIUM who WhatsApp users at the time were the study was conducted.

They were selected through the networking sampling technique. This study managed to obtain 161 students as respondents from all seven faculties (kulliyyah) in IIUM. The respondents came from Kulliyyah of Islamic Revealed Knowledge and Human Sciences (KIRKHS), Kulliyyah of Education (KOED), Ahmad Ibrahim Kulliyyah of Laws (AIKOL), Kulliyyah of Information Communication Technology (KICT), Kulliyyah of Economics and Management Sciences (KENMS), Kulliyyah of Architecture and Environmental Design (KAED), and Kulliyyah of Engineering (KOE).

\section{Instrument and Measurement}

The questionnaire used for data collection in this study was divided into five sections. Section 1 featured general data on the demographics of the respondents, whereas sections 2 to 6 were adapted from different scholars. Section 2 was on patterns of WhatsApp usage, with 10 items. Section 3 was designed to examine the impact of WhatsApp usage on attitude (10 items), whereas Section 4 tapped on the behavior arising from WhatsApp usage (10 items). Finally, Section 5 was designed to evaluate the impact of using WhatsApp on knowledge (10 items).

Items for the patterns of WhatsApp usage were measured using a 5-point Likert-like scale from 1 to 5 , where $1=$ never, $2=$ rarely, $3=$ sometimes, $4=$ often, and $5=$ always. Attitude, behavior, and knowledge were measured on a 5-point Likert scale, where $1=$ strongly disagree, $2=$ disagree, $3=$ slightly agree, $4=$ agree, and $5=$ strongly agree .

An example of patterns of WhatsApp usage items is "I use video call" while for attitude, an example of the items is "I enjoy WhatsApp communication more than face-to-face communication with my lecturer to improve my research." In terms of behavior, an example of the items is "I pay attention and listen during WhatsApp group discussion," while knowledge items included "I know how to discuss my academic problem with my lecturer via WhatsApp."

Each variable was computed to form an overall mean score with a minimum of 1 and a maximum of 5 . To calculate the overall percentage of an item, the mean for the item was multiplied by 20 , which is equivalent to $100 \%$ based on the 5 -point scale. Therefore, an overall percentage was acquired by multiplying the mean score by 100 and dividing by 5 (Wok \& Hashim, 2014). 


\section{Validity and Reliability}

A pilot study $(N=30)$ was conducted to measure the flow of the statements and any other problems that might be faced by the respondents. The questionnaire was also reviewed and approved by an expert in the field of quantitative analysis and research. An internal reliability test was conducted using Cronbach's alpha. The data collected from the pilot study indicated that all items from the four variables were significant and exceeded the minimum Cronbach's alpha value of .70 , indicating the reliability of the variables. Table 1 shows that the results confirm internal cohesiveness and consistency of the variables, with Cronbach's alpha values for the impact of using WhatsApp usage $(\alpha=.929)$, the impact of using WhatsApp on attitude $(\alpha=.925)$, WhatsApp on behavior $(\alpha=.927)$, and the impact of using WhatsApp on knowledge $(\alpha=.879)$. Based on the pilot study results, the variables were strong and reliable enough to proceed with the actual study. As for the actual study, knowledge emerged with the highest score $(\alpha=.958)$, followed by attitude $(\alpha=.941)$, then behavior $(\alpha=.939)$, and lastly WhatsApp usage $(\alpha=.865)$.

Table 1: Reliability Test for the Selected Variables of the Study

\begin{tabular}{|c|l|c|c|c|}
\hline Section & Variables $(\boldsymbol{N = 1 6 1 )}$ & No. of items & \multicolumn{2}{|c|}{ Reliability (Cronbach's $\alpha)$} \\
\hline & & & $\begin{array}{r}\text { Pilot study } \\
(\boldsymbol{N}=\mathbf{2 9})\end{array}$ & Actual study $(\boldsymbol{N}=\mathbf{1 6 1})$ \\
\hline 2 & WhatsApp Usage & 10 & .929 & .865 \\
\hline 3 & Attitude & 10 & .925 & .941 \\
\hline 4 & Behavior & 10 & .927 & .939 \\
\hline 5 & Knowledge & 10 & .879 & .958 \\
\hline
\end{tabular}

\section{Data Analysis}

Statistical Package for the Social Sciences (SPSS) version 22 was used for the analyses of this study. Descriptive and inferential statistical analyses were carried out. For descriptive statistics, frequencies, percentages, mean, and standard deviations were used, while for the inferential statistics, correlation and regression were used to test the hypotheses.

\section{Findings}

\section{Demographic Characteristics of the Respondents}

The study analyzed a sample of 161 respondents from the target population of IIUM postgraduate students. Table 2 shows the details of the demographic characteristics of the respondents. Females made up two-thirds of the respondents $(68.3 \%)$ while the remaining respondents $(31.7 \%)$ were male. About two-fifths of the respondents $(41.0 \%)$ were within the 26-30 years old group, followed by $29.2 \%$ in the $21-25$ years old age group, $14.3 \%$ in the $31-$ 35 years old age group, and $15.0 \%$ in the 36 years old and older age group. Two-fifths of the respondents (40.4\%) obtained a CGPA in the range of 2.81-3.20, 34.2\% were under the 3.614.00 category, while $(18.0 \%)$ were under the category of $2.41-2.80$ and the remaining respondents (7.5\%) were from the 2.00-2.400 and 3.21-3.60 categories combined. Master's students made up three-quarters of the respondents (75.2\%) while the rest (24.8\%) were Ph.D. students. In terms of the mode of study, two-fifths of the respondents $(41.6 \%)$ were on the mixed mode of study, $31.7 \%$ were on the coursework only mode and the rest of them $(26.7 \%)$ were on the research only mode. Regarding their nationality, there were considerably more Copyright (C) GLOBAL ACADEMIC EXCELLENCE (M) SDN BHD - All rights reserved 
Malaysians (75.8\%) than international (24.2\%) students. Further, more than half the number of respondents came from KIRKHS (57.8\%), followed by KENMS (16.1\%) and KOE (9.3\%), while the rest (16.7\%) were from AIKOL, KAED, ENG, and KICT. A substantial number of the respondents $(36.6 \%)$ were in the first year of study, followed by the second year $(30.4 \%)$, fourth year $(21.7 \%)$, and lastly the third year $(11.2 \%)$. Almost all respondents $(98.1 \%)$ reported using WhatsApp messenger in their daily communication, except for $1.9 \%$ of the respondents.

Table 2: Demographic Characteristics of the Respondents

\begin{tabular}{|c|c|c|c|}
\hline Demographic Characteristic & Category & Frequency & Percentage \\
\hline \multirow[t]{3}{*}{ Gender } & Female & 110 & 68.3 \\
\hline & Male & 51 & 31.7 \\
\hline & Total & 161 & 100.0 \\
\hline \multirow{6}{*}{ Age (years old) } & $26-30$ & 66 & 41.0 \\
\hline & $21-25$ & 47 & 29.2 \\
\hline & $31-35$ & 23 & 14.3 \\
\hline & $36-40$ & 19 & 11.8 \\
\hline & 41 and above & 06 & 3.7 \\
\hline & Total & 161 & 100.0 \\
\hline \multirow[t]{6}{*}{ CGPA } & $2.00-2.40$ & 9 & 5.6 \\
\hline & $2.41-2.80$ & 29 & 18.0 \\
\hline & $2.81-3.20$ & 65 & 40.4 \\
\hline & $3.21-3.60$ & 3 & 1.9 \\
\hline & $3.61-4.00$ & 55 & 34.2 \\
\hline & Total & 161 & 100.0 \\
\hline \multirow[t]{3}{*}{ Study level } & Masters & 121 & 75.2 \\
\hline & $\mathrm{PhD}$ & 40 & 24.8 \\
\hline & Total & 161 & 100.0 \\
\hline \multirow{5}{*}{ Mode of study } & Coursework only & 51 & 31.7 \\
\hline & Coursework \& Research & 67 & 41.6 \\
\hline & Research only & 43 & 26.7 \\
\hline & Total & 161 & 100.0 \\
\hline & International & 122 & 75.8 \\
\hline \multirow[t]{2}{*}{ Nationality } & Malaysian & 39 & 24.2 \\
\hline & Total & 161 & 100.0 \\
\hline \multirow[t]{8}{*}{ Kulliyyah } & KIRKHS & 93 & 57.8 \\
\hline & KENMS & 26 & 16.1 \\
\hline & $\mathrm{KOE}$ & 15 & 9.3 \\
\hline & AIKOL & 9 & 5.6 \\
\hline & KAED & 6 & 3.7 \\
\hline & KENG & 6 & 3.7 \\
\hline & KICT & 6 & 3.7 \\
\hline & Total & 161 & 100.0 \\
\hline \multirow[t]{4}{*}{ Year of study } & First & 59 & 36.6 \\
\hline & Second & 49 & 30.4 \\
\hline & Third & 18 & 11.2 \\
\hline & Fourth & 35 & 21.7 \\
\hline
\end{tabular}


Volume 5 Issue 21 (December 2020) PP. 160-181 DOI 10.35631/IJLGC.5210012

\begin{tabular}{lcccc}
\hline & & Total & $\mathbf{1 6 1}$ & $\mathbf{1 0 0 . 0}$ \\
Using WhatsApp & Yes & & 158 & 98.1 \\
& No & & 3 & 1.9 \\
& & Total & $\mathbf{1 6 1}$ & $\mathbf{1 0 0 . 0}$ \\
\hline
\end{tabular}

\section{Patterns of WhatsApp Usage}

Table 3 shows the one-sample $t$-test results for the respondents' patterns of WhatsApp usage. The overall result shows a high overall pattern of WhatsApp usage, with a mean value of 3.782 $(S D=0.666)$ and it was significant $(t=14.889, p=.000)$. This translates that $75.6 \%$ of the respondents had a high level of WhatsApp usage for communication. Specifically, the respondents used WhatsApp to share their documents $(85.7 \%)$, share education links with others $(82.8 \%)$, use emoji $(82.4 \%)$, use voice calls $(80.1 \%)$, use contact sharing feature (76.6\%), share WhatsApp web $(75.6 \%)$, use voice note $(75.1 \%)$, use video and image features $(74.0 \%)$, and use the video call feature (65.8\%). The respondents rarely used the WhatsApp story feature $(57.1 \%)$, with a mean value of $2.857(S D=1.495)$ and it was not significant $(t=$ $-1.212, p=.227)$. Overall, the results imply a high level of WhatsApp usage among IIUM postgraduate students.

Table 3: One-Sample T-Test for Patterns of WhatsApp Usage

\begin{tabular}{|c|c|c|c|c|c|c|c|}
\hline No. & WhatsApp Usage $(N=161)$ & $M *$ & $S D$ & $\%$ & $t^{* * *}$ & $d f$ & $p$ \\
\hline 1 & $\begin{array}{l}\text { I share documents by using } \\
\text { WhatsApp. }\end{array}$ & 4.286 & 0.809 & 85.7 & 20.152 & 160 & .000 \\
\hline 2 & I share links with others. & 4.143 & 0.967 & 82.8 & 14.991 & 160 & .000 \\
\hline 3 & I use Emoji. & 4.124 & 0.998 & 82.4 & 14.286 & 160 & .000 \\
\hline 4 & I use the voice call. & 4.006 & 0.925 & 80.1 & 13.798 & 160 & .000 \\
\hline 5 & I use the contact sharing feature. & 3.832 & 1.062 & 76.6 & 9.944 & 160 & .000 \\
\hline 6 & I use the WhatsApp web. & 3.783 & 1.035 & 75.6 & 9.595 & 160 & .000 \\
\hline 7 & I use the voice note. & 3.758 & 0.992 & 75.1 & 9.689 & 160 & .000 \\
\hline 8 & $\begin{array}{l}\text { I use video and image sharing } \\
\text { features. }\end{array}$ & 3.745 & 1.085 & 74. & 8.712 & 160 & .000 \\
\hline 9 & I use the video call. & 3.292 & 0.997 & 65.8 & 3.712 & 160 & .000 \\
\hline \multirow[t]{2}{*}{10} & I use the WhatsApp story. & 2.857 & 1.495 & 57.1 & -1.212 & 160 & .227 \\
\hline & $\begin{array}{l}\text { Overall mean for WhatsApp } \\
\text { usage }(N=161)\end{array}$ & 3.782 & 0.666 & 75.6 & 14.889 & 160 & .000 \\
\hline
\end{tabular}

*On a 5-point Likert-like scale, where $1=$ never, $2=$ rarely, $3=$ sometimes, $4=$ often, and $5=$ always .

$* *$ test value $=3$

\section{Impact of Using WhatsApp on Knowledge}

The one-sample $t$-test results for the impact of WhatsApp communication on knowledge among IIUM postgraduate students are presented in Table 4. The results show that, on average, the respondents' level of knowledge resulting from the use of WhatsApp communication was high $(t=13.742, p=.000)$. Specifically, they knew they could discuss easily with their lecturers or fellow researchers through WhatsApp whenever they faced any difficulties in their assignments $(80.3 \%)$, they knew how to discuss their academic problems with their lecturers via the platform (80.0\%), they knew that WhatsApp enables them to transfer study links and materials (79.2\%) easily and quickly, they knew that WhatsApp enables them to co-operate and work as Copyright $\odot$ GLOBAL ACADEMIC EXCELLENCE (M) SDN BHD - All rights reserved 
a team (78.3\%), and they knew that WhatsApp has different characteristics, making it suitable to be used for study purposes (78.2\%). Further, the respondents knew that WhatsApp helps them improve their communication skills $(77.2 \%)$, they knew that WhatsApp is an effective way for sharing knowledge (75.9\%), they knew that WhatsApp helps them in choosing the right vocabulary $(75.3 \%)$ and writing skills $(73.9 \%)$, and they knew that WhatsApp is a good learning application (71.2\%). The results indicate that the postgraduate students used WhatsApp for learning purposes.

Table 4: One-Sample T-Test for the Impact of Using WhatsApp on Knowledge

\begin{tabular}{|c|c|c|c|c|c|c|c|}
\hline No. & $\begin{array}{l}\text { Impact of WhatsApp on Knowledge }(N \\
=161)\end{array}$ & $M^{*}$ & $S D$ & $\%$ & $t^{* *}$ & $d f$ & $p$ \\
\hline 1 & $\begin{array}{l}\text { I know I can discuss easily with the } \\
\text { lecturer or other researchers when I face } \\
\text { difficulties in assignments. }\end{array}$ & 4.019 & 0.838 & 80.3 & 5 & 155 & .000 \\
\hline 2 & $\begin{array}{l}\text { I know how to discuss my academic } \\
\text { problem with my lecturer via WhatsApp. }\end{array}$ & 4.000 & 0.888 & 80.0 & 13 & 152 & .000 \\
\hline 3 & $\begin{array}{l}\text { I know Whats App enables easy and quick } \\
\text { transference of links to study materials. }\end{array}$ & 3.962 & 0.886 & 79.2 & 13.550 & 155 & .000 \\
\hline 4 & $\begin{array}{l}\text { I know WhatsApp enables students to co- } \\
\text { operate and work as a team. }\end{array}$ & 3.917 & 0.901 & 78.3 & 12.703 & 155 & .000 \\
\hline 5 & $\begin{array}{l}\text { I know WhatsApp has different } \\
\text { characteristics that can influence its } \\
\text { appropriateness for study purposes. }\end{array}$ & 3.910 & 0.781 & 78.2 & 14. & 155 & .000 \\
\hline 6 & $\begin{array}{l}\text { I kno } \\
\text { comn }\end{array}$ & 3.863 & 0.918 & 77.2 & 11.624 & 152 & .000 \\
\hline 7 & dge via WhatsApp & 3.795 & 0.920 & 75.9 & 10.781 & 155 & .000 \\
\hline 8 & $\begin{array}{l}\text { I kno } \\
\text { choo }\end{array}$ & 3.769 & 0.989 & 75.3 & 9.712 & 155 & .000 \\
\hline 9 & $\begin{array}{l}\text { I know WhatsApp helps me improve my } \\
\text { writing skills. }\end{array}$ & 3.699 & 1.012 & 73.9 & 8.621 & 155 & .000 \\
\hline 10 & $\begin{array}{l}\text { I know WhatsApp is } \\
\text { (App) for learning a }\end{array}$ & 3.564 & 1.060 & 71.2 & 6.643 & 155 & .000 \\
\hline & $\begin{array}{l}\text { Overall mean for knowledge }(N= \\
161)\end{array}$ & 3.848 & 0.771 & 76.9 & 13.742 & 155 & .000 \\
\hline
\end{tabular}

*On a 5-point Likert scale, where $1=$ strongly disagree, $2=$ disagree, $3=$ slightly agree, $4=$ agree, and $5=$ strongly agree.

$* *$ test value $=3$

\section{Impact of WhatsApp Usage on Attitude}

The impact of using the WhatsApp communication platform on IIUM students' attitudes is presented in Table 5. The respondents' attitudes in using the platform are significantly positive, with the mean values ranging from 3.468 and 3.937. The overall mean for the impact of WhatsApp usage on attitude is $3.645(S D=0.842)$ with $t=9.629(p=.000)$. The highest mean value was recorded for the item "I feel that WhatsApp is more effective in personal communication compared to other social media platforms" (78.7\%) whereas the lowest was 
obtained by "I enjoy sharing my daily activities in WhatsApp story." The respondents claimed that they preferred WhatsApp text than voice communication $(78.1 \%)$, they liked to reply in WhatsApp groups frequently when necessary (74.5\%), they like acquiring study-related knowledge by attending meetings/gatherings with classmates via WhatsApp (74.1\%), and they preferred replying to WhatsApp messages immediately (73.8\%). Further, they liked doing their project because of their active connection with their classmates via WhatsApp (73.8\%), they felt that they had improved their studies by establishing connections with classmates via WhatsApp (73.5), they felt comfortable using WhatsApp compared to E-mail communication (72.1\%), and they enjoyed WhatsApp communication more than face-to-face communication with their lecturers to improve their research $(69.3 \%)$. The results show that the postgraduate students had a positive attitude regarding the usage of WhatsApp for communication.

Table 5: One-Sample T-Test for the Impact of WhatsApp Usage on Attitude

\begin{tabular}{|c|c|c|c|c|c|c|c|}
\hline No. & $\begin{array}{l}\text { WhatsApp Usage on Attitude }(N \\
=161)\end{array}$ & $M^{*}$ & $S D$ & $\%$ & $t^{* * *}$ & $d f$ & $p$ \\
\hline 1 & $\begin{array}{l}\text { I feel that WhatsApp is more } \\
\text { effective in } \\
\text { communication compared to other } \\
\text { social media. }\end{array}$ & 3.937 & 0.914 & 78.7 & 12.872 & 157 & .000 \\
\hline 2 & $\begin{array}{l}\text { I prefer WhatsApp text } \\
\text { communication than voice } \\
\text { communication. }\end{array}$ & 3.905 & 0.989 & 78.1 & 11.503 & 157 & .000 \\
\hline 3 & $\begin{array}{l}\text { I like to reply in WhatsApp groups } \\
\text { frequently if it is necessary. }\end{array}$ & 3.728 & 1.092 & 74.5 & 8.376 & 157 & .000 \\
\hline 4 & $\begin{array}{l}\text { I like acquiring study-related } \\
\text { knowledge by attending (via } \\
\text { WhatsApp) meetings/gatherings } \\
\text { with my fellow classmates. }\end{array}$ & 3.709 & 0.959 & 74.1 & 9.284 & 157 & .000 \\
\hline 5 & $\begin{array}{l}\text { I prefer to reply to WhatsApp } \\
\text { messages immediately. }\end{array}$ & 3.690 & 0.909 & 73.8 & 9.537 & 157 & .000 \\
\hline 6 & $\begin{array}{l}\text { I like doing my project because of } \\
\text { my active connection with my } \\
\text { classmates via WhatsApp. }\end{array}$ & 3.690 & 1.021 & 73.8 & 8.490 & 157 & .000 \\
\hline 7 & $\begin{array}{l}\text { I feel I have improved my studies } \\
\text { because of my established } \\
\text { connection with my classmates via } \\
\text { WhatsApp. }\end{array}$ & 3.677 & 0.897 & 73.5 & 9.482 & 157 & .000 \\
\hline 8 & $\begin{array}{l}\text { I feel comfortable in WhatsApp } \\
\text { communication than E-mail } \\
\text { communication. }\end{array}$ & 3.608 & 1.166 & 72.1 & 6.547 & 157 & .000 \\
\hline 9 & $\begin{array}{l}\text { I enjoy WhatsApp communication } \\
\text { more than face-to-face } \\
\text { communication with my lecturer to } \\
\text { improve my research. }\end{array}$ & 3.468 & 1.275 & 69.3 & 4.616 & 157 & .000 \\
\hline 10 & $\begin{array}{l}\text { I enjoy sharing my daily activities } \\
\text { in WhatsApp story. }\end{array}$ & 3.044 & 1.442 & 60.8 & .386 & 157 & .700 \\
\hline
\end{tabular}




\section{Overall Mean for Attitude $(N=161)$ \\ $\begin{array}{llllll}3.645 & 0.842 & 69.3 & 9.629 & 157 & .000\end{array}$}

*On a 5-point Likert scale, where $1=$ strongly disagree, $2=$ disagree, $3=$ slightly agree, $4=$ agree, and $5=$ strongly agree.

$* *$ test value $=3$

\section{Behavioral Impact}

The one-sample $t$-test results for behavioral impact are shown in Table 6. Overall, the respondents' level of behavioral impact is significantly high $(t=14.976, p=.000 ; M=3.851$, $S D=0.714)$. Specifically, more than three-quarters of the respondents $(77.0 \%)$ had a high level of behavioral impact resulting from WhatsApp usage. The item with the highest mean $(M=$ $4.025, S D=0.844)$ is the respondents reported that they depended on WhatsApp for most of their communication in their daily life $(80.5 \%)$, whereas the item with the lowest behavioral impact is they were inspired by their friends' and lecturer's WhatsApp success stories $(68.2 \%)$ $(M=3.411, S D=1.053)$. The other positive behavioral impacts resulting from WhatsApp usage include: by joining many other study groups, they remained updated on assignments (80.1); by using multiple WhatsApp features like text, voice, video and others they could save time by not using other messaging applications (78.7\%); they checked WhatsApp messages in the morning to keep informed on current issues $(78.3 \%)$; they checked their platform frequently (78.2\%); they accepted it when people took a long time to reply $(77.3 \%)$; they found WhatsApp useful for getting updated information from their study groups $(77.2 \%)$; and they admitted that they paid attention and listened during WhatsApp discussions (73.4\%). The results imply that postgraduate students at IIUM behave positively while using WhatsApp for different academicrelated purposes.

Table 6: One-Sample $T$-Test for Behavioral Impact

\begin{tabular}{|c|c|c|c|c|c|c|c|}
\hline No. & Behavioral Impact $(N=161)$ & $M^{*}$ & $S D$ & $\%$ & $t^{* * *}$ & $d f$ & $p$ \\
\hline 1 & $\begin{array}{l}\text { I am seriously dependent on WhatsApp } \\
\text { for most of my communication. }\end{array}$ & 4.025 & 0.844 & 80.5 & 15.266 & 157 & .000 \\
\hline 2 & By joining many study groups & & & & & & \\
\hline & $\begin{array}{l}\text { WhatsApp, I remain updated on } \\
\text { assignments and homework. }\end{array}$ & 4.006 & 0.848 & 80.1 & 14 & 157 & .000 \\
\hline 3 & $\begin{array}{l}\text { By using multiple features of WhatsApp } \\
\text { (e.g., text, photo, video, forwarding } \\
\text { information, and voice message), I can } \\
\text { save time by not using other messaging } \\
\text { apps. }\end{array}$ & 3.5 & 0.886 & 78.7 & & 157 & .000 \\
\hline 4 & $\begin{array}{l}\text { Checking WhatsApp messages } \\
\text { immediately after waking up in the } \\
\text { morning keeps me informed of the } \\
\text { current updates. }\end{array}$ & 3.917 & 0.786 & 78.3 & 14.554 & 155 & .000 \\
\hline 5 & I check my WhatsApp frequently. & 3. & 0.869 & 78.2 & 72 & 157 & .000 \\
\hline 6 & $\begin{array}{l}\text { I tended to check my WhatsApp } \\
\text { frequently. }\end{array}$ & 3 & 0 . & 77.9 & 67 & 157 & .000 \\
\hline 7 & $\begin{array}{l}\text { I accept it when people take a long time } \\
\text { to reply in WhatsApp. }\end{array}$ & 3.867 & 0.945 & 77.3 & 11.533 & 157 & .000 \\
\hline
\end{tabular}


8 I find WhatsApp useful for getting updated information from my study groups.

9 I pay attention and listen during WhatsApp group discussions.

\section{$\begin{array}{llllll}3.671 & 0.987 & 73.4 & 8.458 & 154 & .000\end{array}$}

10 I get inspired by students' and lecturers' success stories in WhatsApp.

*On a 5-point Likert scale, where $1=$ strongly disagree, $2=$ disagree, $3=$ slightly agree, $4=$ agree, and $5=$ strongly agree.

$* *$ test value $=3$

\section{Hypothesis Testing: Correlation and Regression Analysis}

To test whether attitude mediated the relationships of WhatsApp usage and knowledge with behavioral impact among IIUM postgraduate students, a zero-order correlation was performed to measure the effect of the relationships between the variables. Based on the results, all variables tested emerged statistically significant. The strengths of the relationships were found to be both weak and strong and they turned out to be highly statistically significant (Table 7).

Table 7: Zero-Order and Partial Correlation Between Attitude, Knowledge, and Behavioral Impact of WhatsApp Communication Among IIUM Postgraduate Students

\begin{tabular}{llccc}
\hline Control & Variable $(\boldsymbol{N}=\mathbf{1 5 4})$ & \multicolumn{1}{c}{ Behavior } & Usage & Knowledge \\
None & Behavior & 1 & & \\
& Usage & $r=.566, p=.000$ & 1 & 1 \\
& Knowledge & $r=.813, p=.000$ & $r=.462, p=.000$ & 1 \\
& Attitude & $r=.826, p=.000$ & $r=.570, p=.000$ & $r=.791, p=.000$ \\
Attitude & Usage & $r=.206, p=.005$ & 1 & \\
& Knowledge & $r=.463, p=.000$ & $r=.022, p=.392$ & 1 \\
\hline
\end{tabular}

The results illustrate that behavioral impact had a moderate positive relationship with WhatsApp usage $(r=.556, p=.000)$ and very strong positive relationships with knowledge $(r$ $=.813, p=.000)$ and attitude $(r=.826, p=.000)$. Hence, $\mathrm{H} 1, \mathrm{H} 2$, and $\mathrm{H} 5$ are supported. Besides, attitude had a positive and statistically significant relationship with WhatsApp usage $(r=.570, p=.000)$ and knowledge $(r=.791, p=.000)$. Therefore, $\mathrm{H} 3$ and $\mathrm{H} 4$ are also supported. Since all hypotheses are supported, the mediating effect of attitude was tested. Attitude was able to partially mediate the relationships of WhatsApp usage $(r=.206, p=.005)$ and knowledge $(r=.463, p=.000)$ with behavioral impact. This is because the correlation between WhatsApp usage and knowledge was still significant although with a reduction of the value of the relationship between WhatsApp usage and knowledge on behavioral impact. Hence, hypotheses H6 and H7 are partially supported.

Mediating Effect of Attitude on the Relationship Between WhatsApp Usage and Knowledge This section tests the mediating effect of attitude on the relationships of WhatsApp usage and knowledge with behavioral impact using hierarchical regression (Table 8). Model 1 results 
indicate that all the dimensions for usage and knowledge are predictors of attitude $(F(156)=$ $162.173, d f 1=2, d f 2=152, p=.000)$.

Table 8: Hierarchical Regression Analysis for Behavior With Usage and Knowledge

\begin{tabular}{|c|c|c|c|c|c|c|}
\hline Model & Variable & $\begin{array}{c}\text { Unstandardized } \\
\text { B }\end{array}$ & $\begin{array}{l}\text { coefficients } \\
\text { Std. Error }\end{array}$ & $\begin{array}{c}\text { Standardized } \\
\text { coefficients } \\
\beta \\
\end{array}$ & $t$ & $\rho$ \\
\hline \multirow{3}{*}{1} & Constant & -.354 & .241 & - & -1.469 & .114 \\
\hline & Usage & .321 & .060 & .260 & 5.030 & .000 \\
\hline & Knowledge & .246 & .056 & .671 & 13.008 & .000 \\
\hline \multicolumn{7}{|c|}{$\begin{array}{c}F(156)=162.173, d f 1=2, d f 2=152 \rho=.000, R=.824, R^{2}=.679, \text { adj } R^{2}=.675 ; F \\
\text { change }=162.173, d f 1=2, d f 2=153, \rho=.000\end{array}$} \\
\hline \multirow{4}{*}{2} & Constant & -.598 & .222 & & -2.696 & .008 \\
\hline & Usage & .186 & .062 & .150 & 2.991 & .003 \\
\hline & Knowledge & .383 & .077 & .354 & 4.975 & .000 \\
\hline & Behavior & .538 & .091 & .453 & 5.919 & .000 \\
\hline \multicolumn{7}{|c|}{$\begin{array}{c}F(156)=143.842, d f 1=1, d f 2=153 \rho=.000, R=.860, R^{2}=.740, \text { adj } R^{2}=.734 ; F \\
\text { change }=35.033, d f 1=1, d f 2=152, \rho=.000\end{array}$} \\
\hline
\end{tabular}

Model 1 shows that all the variables are positive and significant. Knowledge $(\beta=.671)$ has the highest beta weight compared to patterns of WhatsApp usage $(\beta=.260)$, whereas in Model 2, the results exhibit a reduction in the beta weight of the variables, but they remain statistically significant. Here, knowledge is reduced to $\beta=.354$ while patterns of WhatsApp usage is at $\beta$ $=.150$. This implies that the introduction of attitude as a mediator affected all the values of the variables and reduced the beta weight, but they remained significant. Therefore, it can be concluded that attitude partially mediated the relationships among the variables.

\section{Discussion and Conclusion}

This study involved 161 respondents from IIUM, where postgraduate males and females were equally represented. The results show a high level of knowledge and attitude among the students, as indicated by the mean score results above the test value of 3 . This study supports Malik et al. (2013), which found that the more knowledge students have, the more positive is their attitude towards a particular issue. This study further found high positive levels of WhatsApp usage, knowledge, attitude, and behavioral impact among IIUM postgraduate students. It can be concluded that IIUM students widely use WhatsApp for their academic purposes. The study has also proven the mediating effect of attitude on the relationships of WhatsApp usage and knowledge with behavior, implying that students with positive and adequate knowledge will always prefer to use the WhatsApp communication application due to its efficiency and speed in delivering messages. Hence, all hypotheses of the study are supported.

The findings of the study also support the usage of media richness theory that encourages the convenient use of Internet-based communication systems via messaging applications, that is, WhatsApp. This because WhatsApp groups are used for some specific purposes, namely, communicating with students, enhancing social atmosphere, initiating dialogues, and 


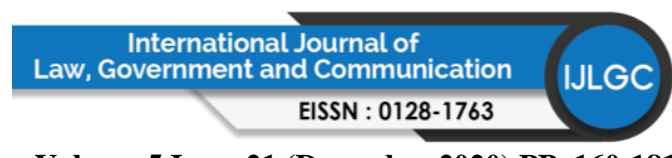

Volume 5 Issue 21 (December 2020) PP. 160-181

DOI 10.35631/IJLGC.5210012

promoting the value of sharing among students as well as for a learning platform. This is due to the ability and capability of WhatsApp communication to provide rich information. Therefore, media richness theory is appropriately applied in this study.

\section{Limitations and Suggestions of the Study}

The study considered only postgraduate students from one university as the respondents. Future studies should include other levels of students and extend to other universities to widen the scope of the study for better representation and applicability of the findings. In addition to WhatsApp, there are other platforms that lecturers and students use for communication purposes pertaining to academic endeavors and in building relationships. Therefore, future studies should look at other social networking platforms to examine students' usage, knowledge, attitude, perception, and behavioral intensity towards those platforms.

Moreover, future studies should explore using other theories in highlighting the attitude, perception, and behavior of students in learning institutions while using social networking sites to communicate with their lecturers and teachers. These other theories include learning theory, diffusion of innovation theory, cultivation theory, dependency theory, and social learning theory.

\section{References}

Abaido, G., \& El-Messiry, H. (2016). Efficiency of WhatsApp as a means of disseminating educational information: IT \& Knowledge Excellence, (5), 1-6.

Abdelraheem, A. Y., \& Al-Rabane, A. H. (2005). Utilisation and benefits of instructional media in teaching social studies courses as perceived by Omani students: Malaysian Online Journal of Instructional Technology, (2), 1-8.

Acton, B., \& Koum, J. (2014). WhatsApp blog. Retrieved on July 13, 2020. http://blog. Whatsapp.com/

Alghamdi, E. A., Rajab, H., \& Rashid Shah, S. (2016). Unmonitored student's self-created Whats App groups in distance learning environments: A collaborative learning tool or cheating technique: International Journal of Research Studies in Educational Technology, (5), 71-82.

Ansiem George, S. Preetha and Pramod S. K (2018). Whatsapp Use Behaviour in Relation to Social Interaction Anxiety and Personality among Students: International Journal of Engineering \& Technology, (7), 1071-1077.

Bere, A. (2013). Using mobile instant messaging to leverage learner participation and transform pedagogy at a South African University of Technology: British Journal of Educational Technology, (4), 544-561.

Bernama. (2017, Sept 12). Malaysians are world's largest WhatsApp users. New Straits Times. $\begin{array}{llll}\text { Retrieved on July } & 7020 .\end{array}$ https://www.nst.com.my/lifestyle/bots/2017/09/278936/malaysians-are-worldslargest-WhatsApp-users

Bers, M. U. (2010). New media and technology: Youth as content creators. San Francisco, CA: Jossey-Bass/Wiley.

Bouhnik, D., \& Deshen, M. (2014). WhatsApp goes to school: Mobile Instant messaging between teachers and students: Journal of Information Technology Education, (13), 217-231. 
Boyinbode, O. K., Agbonifo, O. C., \& Ogundare, A. (2017). Supporting mobile learning with WhatsApp base on Media Richness: Circulation in Computer Science, (3), 37-46.

Chaffey, D. (2016). Statistics on consumer mobile usage and adoption to inform your mobile marketing strategy mobile site design and app development. Retrieved on July 1, 2020. http://www.smartinsights.com/mobile-marketing/mobile-marketing-analytics/mobilemarketing-statisti cs/

Connolly, T., Willis, J., \& Lloyd, M. (2019). Evaluating teacher and learner readiness to use Facebook in an Australian vocational setting: Studies in Continuing Education, (1), 6175.

Cox, J. T., \& Rethman, K. M. (2011). Setting expectations: Social networking at work. Ohio Lawyer, 25, 17-19. Retrieved on July 14, 2020. https://www.coursehero.com/file/33002946/Setting-Expectations-Social-Networkingat-Workpdf/

Davidovich, R. (2010). Beyond school improvement: The journey to innovative leadership. Thousand Oaks, CA: Corwin.

Davidovitch, N., \& Yavich, R. (Nov 2016). WhatsApp messaging: Achievements and success in academia: International Journal of Higher Education, (4), 255-261.

Doering, A., Lewis, C., Veletsianos, G., \& Besel, K. N. (2008). Preservice teachers' perceptions of instant messaging in two educational contexts: Journal of Computing in Teacher Education, (1), 5-12.

Falloon, G. (2011). Making the connection: Moore's theory of transactional distance and its relevance to the use of a virtual classroom in postgraduate online teacher education: Journal of Research on Technology in Education, (3), 187-209.

Fattah, S. F. E. S. A. (2015). The effectiveness of using WhatsApp messenger as one of mobile learning techniques to develop students' writing skills: Journal of Education and Practice, (32), 115-127.

Jisha, K., \& Jebakumar, K. (2014). WhatsApp: A trend setter in mobile communication among chennai youth: IOSR Journal of Humanities and Social Science, (9), 1-4.

Karapanos, E., Gouveia, R., \& Teixeira, P. (2016). Need fulfillment and experiences on social media: A case on Facebook and WhatsApp: Computers in Human Behavior, 55, 888897.

Khan, T., Kend, M., \& Robertson, S. (2016). Use of social media by university accounting students and its impact on learning outcomes: Accounting Education, (6), 534-567.

Kitsantas, T., Chirinos, D. S., Hiller, S. E., \& Kitsantas, A. (2015). An examination of Greek college students' perceptions of positive and negative effects of social networking use. In T. Issa, P. Isaias, \& P. Kommers (Eds.), Social Networking and Education. Springer Pub.

Latonero, M., \& Shklovski, I. (2011). Emergency management, Twitter, and social media evangelism: International Journal of Information Systems for Crisis Response and Management, (4), 67-86.

Litchfield, A., Dyson, L. E., Lawrence. E., \& Zmijewska, A. (2007). Directions for mobilelearning research to enhance active learning (Conference Proceedings). Paper Presented at ASCILITE Singapore. pp. 587-596.

MacGrath, M. (2005). Beyond behavior management: Manage or Motivate?: Education Review, (1), 57-64.

Copyright $\odot$ GLOBAL ACADEMIC EXCELLENCE (M) SDN BHD - All rights reserved 


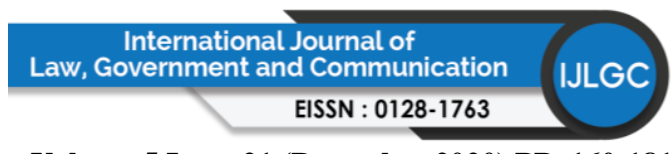

Volume 5 Issue 21 (December 2020) PP. 160-181 DOI 10.35631/IJLGC.5210012

M. bukusa, N. R. (2018). Perceptions of students on the Use of WhatsApp in Teaching Methods of English as Second Language at the University of Namibia: Journal of Curriculum and Teaching, (2), 112-119.

Mehmood, S., \& Taswir, T. (2013). The effects of social networking sites on the academic performance of barriers of social network sites in higher education. In T. Issa, P. Isaias, \& P. Kommers (Eds.), Social networking and education, USA: Springer.

Mistar, I. B. and Embi, M. A. (2016) Students' Perception On The Use Of Whatsapp As A Learning Tool In Esl Classroom: Journal of Education and Social Sciences, (4), 96104.

Motiwalla, L. (Nov 2007). Mobile learning: A framework and evaluation: Computers \& Education, (3), 581-596.

Nassar, D. (2016). Using social network as an education enhancement tools a case study of using WhatsApp in Princess Nourah University: Journal of Educational and Instructional Studies in the World, (1), 18-21.

Nicholson, S. (2011). Infographics: The history of online social networking. Retrieved on July 14, 2020. https://www.socialmediatoday.com/news/infographic-the-history-of-onlinesocial-networking/475388/

Patel, K. M. (2014). Customer satisfaction towards WhatsApp (Degree Thesis at Hemchandracharya North Gujarat University.

Plana, M. G. C., Escofet, M. I. G., Figueras, I. T., Gimeno, A., Appel, C., \& Hopkins, J. (2013). Improving learners' reading skills through instant short messages: A sample study using WhatsApp. 4th World-CALL Conference (10-13 July). Glasgow, UK.

Pornsakulvanich, V., Rubin, A. M., \& Haridakis, P. M. (2008). The influence of dispositions and Internet motivation on online communication satisfaction and relationship closeness: Computers in Human Behavior, (5), 2292-2310.

Pramod, S. K. (2016). WhatsApp use behavior and social interaction anxiety among students: Review of Research, (10), 1-9.

Riyanto, A. (2013). English language learning using 'WhatsApp' application. Akhmad Riyanto Blog. Retrieved on July 2020. https://akhmadriyantoblog.wordpress.com/2013/07/21/english-language-learningusing-WhatsApp-application/

Schultz, K. (2011). Friends on Facebook: The impact of Facebook on interpersonal friendships of female college students (Unpublished Master's Thesis at Gonzaga University). $\begin{array}{llll}\text { Retrieved on July } 2020 . & \end{array}$ https://pdfs.semanticscholar.org/85ae/323281e373e8c86f1f680b8895a4c206fa1f.pdf? _ga $=2.57403823 .466554707 .1577550827-128712129.1542688328$

Singh, S., \& Franklin, S. (2015). WhatsApp-messenger fever on students. ASM's International E-Journal on Ongoing Research in Management and IT, E-ISSN-2320-0065.

Smit, I. (2012). WhatsApp with BlackBerry: Can messengers (BBM) be MXit? The 14th Annual Conference on World Wide Web Applications, Cape Peninsula University of Technology, Cape Town, South Africa.

Smits, M., \& Mogos, S. (2013). The impact of social media on business performance (Conference Proceedings). The 21st European Conference on Information Systems. Utrecht.

Terzi, B., Bulut, S., \& Kaya, N. (2019). Factors affecting nursing and midwifery students' attitudes toward social media: Nurse Education in Practice, 35, 141-149. 
Yeboah, J., \& Ewur, G. D. (2014). The impact of WhatsApp messenger usage on students performance in Tertiary Institutions in Ghana: Journal of Education and Practice, (6), $157-164$.

Yue, Z. Z. (2014). Which will you choose, e-mail or WeChat? Media richness, social presence, self-esteem and media preference among Chinese young people (unpublished MA Thesis at Chinese University of Hong Kong). 